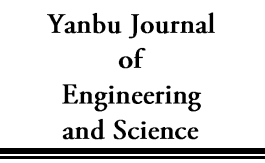

ISSN: $1658-5321$
Vol. 6, April $2013(1434 \mathrm{H})$

www.yjes.org.sa

\title{
SOME MECHANICAL PROPERTIES OF RUBBERIZED CONCRETE
}

\author{
Nadim A. Emira ${ }^{1}$ and Nasser S. Bajaba ${ }^{2}$ \\ 1 Yanbu Industrial College, Yanbu Al-Sinaiyah, Kingdom of Saudi Arabia \\ On leave from Mechanical Design \& Production Department, Faculty of Engineering, Zagazig University, , Egypt \\ E-mail:nemira@yic.edu.sa \\ 2 Yanbu Industrial College, Yanbu Al-Sinaiyah, Kingdom of Saudi Arabia
}

\begin{abstract}
A waste tire disposal is a major problem and the finding of the environmental correct and potentially attractive method is a greatest challenge. One of the potential means of utilizing the waste tires is to process this waste material for the protection of the environment and society. This study explores the effects of rubber particles on some mechanical properties of concrete. On other word the aim of this work is achieved to highlight the use of rubber tires as a partial replacement of fine aggregate to produce rubberized concrete. For the sake of various engineering application promising effects, three different sizes are involved as partial replacements of crumbed rubber at $(10,20$, and $30 \%$ ) by volume of fine aggregate in concrete mixtures. Three different concrete sets were prepared and tested in terms of compression, stress-strain manners and workability evaluation through weight and permeability tests. The results revealed that using crumb rubber reduced all types of compressive strength. The results also indicated that different crumb rubber sizes have some influence on the workability, which varied between light and moderate structural weight concrete.
\end{abstract}

Keywords: Concrete, Tire Rubber, Rubberized Concrete, Concrete Workability

\section{INTRODUCTION}

\subsection{SOLID WASTES}

Many of the wastes produced today will remain in the environment for hundreds, perhaps thousands of years. As the world population grows, the amount and type of waste are being increased. The creation of non-decaying waste material, combined with a growing consumer population, has resulted in a waste disposable crisis; one solution to this crisis lies in recycling waste into useful products, continuously decreasing the number of landfills due to the reuse of these materials. Therefore, over the past few years, a number of researches have been focused on the use of waste tires in different shapes and sizes in concrete.

The use of solid wastes is not a new concept in concrete industries, the possibility of using solid wastes as an aggregate in concrete has received increasing attention in recent years as a promising solution to the escalating solid waste problem. Therefore from the environmental point of views, cement and concrete industries can be considered environmentally friendly. The use of fly ash, silica fumes and blast furnace slag in cement and concrete industries is helpful for both manufacturing of cemented products with improved durability and for reducing the disposal waste material [1 and 2]. 


\subsection{Problem of Rubber Wastes}

The waste is divided into solid waste, liquid waste and gaseous waste. There are lots of disposal ways for liquid and gaseous waste materials. Unlike solid waste materials such as PET bottles, papers, steel etc., can be recycled without affecting the environment. But there is no way to dispose some solid wastes such as waste tires. Similarly, there is another challenge to the human society in the form of carbon dioxide emission and green house emission, which are considered as another type of waste, which is threatening the universe [3].

The replacement of aggregates with granulated rubber waste deteriorates mechanical properties of concrete. The decrease of compressive strength of concrete after modification with rubber waste is explained by the more elastic and softer rubber particles compared to the sand particles [4, 5, and 6]. The second reason for concrete compressive strength reduction is significantly lower compressive strength of the crumbed rubber particles compared to the strength of concrete aggregates [7 and 8]. Deterioration of the mechanical properties of concrete with rubber additives is also explained by low adhesion among the rubber particles and cement matrix [9 and 10]. However, as observed in [11 and 12], there is a strong adhesion of contact zone between the rubber particles and cement mix; therefore this presumption should be rejected. Most compressive strength reduction was observed in concrete mixtures with adding $20 \%$ of tires rubber waste additive, [13 and 14]. The addition of tire rubber softens the elastic stress-strain response, yielding Young's modulus as low as $10,000 \mathrm{MPa}[15,16$, and 17].

\subsection{APPLiCations AND ADVANTAgES OF RUBBERIZED CONCRETE}

The rubberized concretes are affordable, cost effective and withstand more pressure, impact and temperature when compared it with conventional concrete. Studies show the CRC (crumb rubber concrete) specimens remained intact after failure (did not shatter) compared to a conventional concrete mix. The impact resistance of rubberized concrete was higher, and it was particularly evident in concrete specimens aggregated with thick rubber [18].

Moreover, the unique qualities of rubberized concrete will find new areas of usage in highway constructions as a shock absorber, in sound barriers as a sound absorber and also in buildings as an earthquake shock-wave absorber. It reduces plastic shrinkage cracking and reduces the vulnerability of concrete to catastrophic failure.

Currently, the waste tire rubberized concrete is used in precast sidewalk panel, non-load bearing walls in buildings and precast roof for green buildings [19]. It can be widely used for development related projects such as roadways or road intersections, recreational courts and pathways, and skid resistant ramps [18]. With this new property it is projected that these concretes can be used in architectural applications such as nailing concrete, where high strength is not necessary, in wall panels that require low unit weight, in construction elements and Jersey barriers that are subject to impact, in rail road to fix rails to the ground [20].

The present work investigates the effects of adding rubber particles on some mechanical properties of concrete. On other word the aim of this work is achieved to use rubber tires as a partial replacement of fine aggregate to produce rubberized concrete. This research therefore aims at performing sets of reliable 
tests for some mechanical properties and behavior of concrete containing rubber aggregate. The present investigation is expected to offer more understanding of the mechanical properties of rubberized concrete.

\section{EXPERIMENTAL PROGRAM}

\subsection{DESIGN AND MATERIAL}

Concrete is a mixture of Cement, Sand (fine aggregate), small stone or gravel (Coarse aggregate) and water. It has many applications, from fence posts to motorway bases and, because of this; there are many different ratios for the constituents to be mixed.

This research will concentrate on a general purposed mix suitable for garden paths, fence posts, and shallow retaining wall foundations. A detail of this mixture proportions for this mixture except for the ready-mixed concrete is selected according to Saudi Building Code Committee [21]. The composition of cementitious material used in this mixture was $1 \mathrm{~kg}$ Cement, $4 \mathrm{~kg}$ Coarse aggregate (12:18 $\mathrm{mm}$ ), $2 \mathrm{~kg}$ sand (Fine aggregate, $0: 3 \mathrm{~mm}$ ), and 0.55 water/cement ratio. These mixtures ingredients were used as a reference. Such mixes reflect the local design mixes used by the ready mix plants.

The waste rubber used in this research was obtained from Saudi Rubber Products Co. (SARPC), Al-Khobar with three different sizes; $(3.0-4.0 \mathrm{~mm}), \quad(4.0-5.0 \mathrm{~mm})$, and $(5.0-$ $6.0 \mathrm{~mm})$.

The ratios of crumbed rubber that are used as a partial replacement for fine aggregates (sand) by volume are $(0 \%, 10 \%, 20 \%$, and $30 \%)$ for production of concrete. The volumetric content is always higher than its content by weight due to low specific gravity relative to the other ingredients. The crumbed rubbers that are used in this research are classified into three sets namely; $(3.0-4.0 \mathrm{~mm}), \quad(4.0-$ $5.0 \mathrm{~mm})$, and $(5.0-6.0 \mathrm{~mm})$.

\subsection{Casting ANd Curing}

Cylindrical specimens of $(150 \times 300) \mathrm{mm}$ in size were specified. The smaller specimens tend to be easier to make and handle in the field and the laboratory. All laboratory batches of concrete were cast inside the laboratory of, OSAIMI ENGINEERING OFFICE (Yanbu Al Sinaiyah), in a small capacity drum mixer to check if silica fume was properly mixed during initial mixes. The mixing, casting, and curing conformed to [22]. The cylindrical samples were cast in steel molds to eliminate any effect that could result from plastic or cardboard molds. The standard size cylindrical specimens were cast in two layers with each layer vibrated in a vibrating table for 35 to 45 seconds. The specimens were de-molded after $24 \mathrm{hr}$, and then subjected for 28 days to standard moist curing by immersing them in curing tanks containing lime saturated water at $23^{\circ} \mathrm{C}$. The specimens under test are tested after 28 days curing time.

\subsection{Testing the Compressive Strength of CONCRETE}

Concrete mixtures can be designed to provide a wide range of mechanical and durability properties to meet the design requirements of a structure. The compressive strength of concrete is the most common performance measure used by the engineer in designing buildings and other structures. Cylindrical specimens are tested in accordance with ASTM C 39, Standard Test Method for Compressive Strength of Cylindrical Concrete Specimens. A test result is the average of three standard-cured strength specimens made from the same concrete sample and tested at the same age.

After needed materials were prepared with specifications and concrete mix design 
according to Saudi Building Code Committee [21], laboratory specimens were made in three sets. To obtain the reliable result, three samples were made and tested for each type of test.

First set: In this set four different types of samples were used, namely; control concrete samples, rubberized concrete samples with $10 \%, 20 \%$, and $30 \%$ partial replacement for fine aggregates (sand) by volume. The size of (3.0 - 4.0) $\mathrm{mm}$ of crumbed rubber was used for this set.

The second and the third sets contain the previous four different types of samples of the first set, and also sizes of $(4.0-5.0) \mathrm{mm}$ and (5.0-3.0) $\mathrm{mm}$ crumbed rubber were used for both second and third set respectively. The ratio of the composition of material used for the mixes were $1 \mathrm{~kg}$ Cement, $4 \mathrm{~kg}$ Coarse aggregate $(12: 18 \mathrm{~mm}), 2 \mathrm{~kg}$ sand (Fine aggregate, $0-3 \mathrm{~mm}$ ), and 0.55 water/cement ratio. These ratios were kept constant for all concrete mixes. The volumetric content is always higher than its content by weight due to low specific gravity relative to the other ingredients. The compressive strength was measured in compliance with ASTM C39 standard test method [22]. To perform compression tests a $3000 \mathrm{kN}$ Auto Comp 2 compression machine manufactured by Controls was used. The load accuracy of this machine is $\pm 1 \%$. The machine used has a high stiffness frame with four pre-stressed columns to ensure maximum rigidity and stability and is suitable for cylinder and cube testing.

\section{RESULTS AND DISCUSSION}

\subsection{PROPERTY OF CONCRETE COMPRESSIVE STRENGTH}

Details and assigned designation of the three sets are given in Table 1 . As shown in Table 1 the three sets composition as a result of adding different percentages of crumb rubber with different sizes on concrete compressive strength after 28 days curing times.

In Figure 1 shows the variation of crumbed rubber of different sizes namely; $(3.0-4.0 \mathrm{~mm})$, $(4.0-5.0 \mathrm{~mm})$ and $(5.0-6.0 \mathrm{~mm})$ at different percentages inside a potion slice of the cylindrical specimen. It is crystal clear that, the chance to find a uniform distribution of crumbed rubber inside the tested specimens is impossible. The composition is different from a potion slice to another.

The relationship between the percentage of crumb rubber content and the reduction in compressive strength is presented in Figure 2. The detailed examination of Figure 2 shows that the reduction in compressive strength increases as both of the crumbed rubber ratios and sizes increase. In other words, when adding $10 \%$ crumbed rubber, the reduction in compressive strength was $(9.8 \%, 11.76 \%$, and $12.98 \%)$ for the sizes $(3.0-4.0),(4.0-$ 5.0 ), and (5.0-6.0) $\mathrm{mm}$ respectively.

Similarly at $20 \%$ crumbed rubber, the reduction was $(22.98 \%, 24.98 \%$, and $26.66 \%)$ for the same sizes. And for $30 \%$ crumbed rubber, the reduction was $(38 \%, 41.17 \%$, and $45.1 \%)$ for the same pervious sizes. It is evident that the use of crumb rubber reduced the compressive strength. As expected, the higher the rubber content in the mix, the higher the reduction in compressive strength.

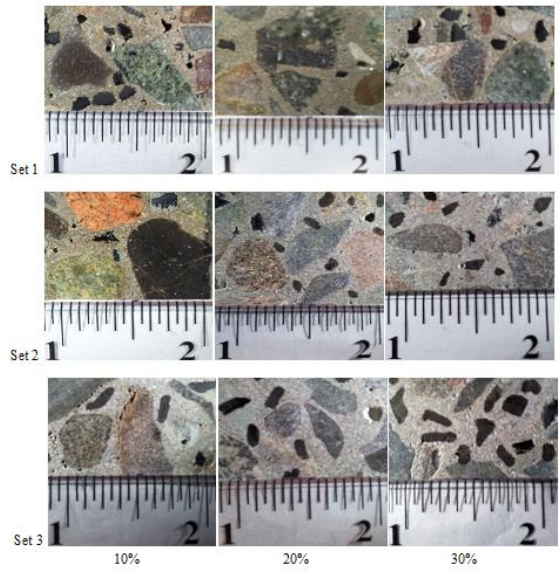

Fig.1. Slices of tested specimens of the three sets with different rubber sizes and percentage 


\subsection{Property OF CONCRETE STRESS-STRAIN CURVE}

The relationship between stress and strain of the three different sizes rubber contents groups, are shown in Figures (3, 4 and 5) with three different percentage namely; (10\%, 20\%, and 30\%) respectively. The stress-strain curves represent results from cube specimens with dimension $(50 \times 50 \times 50 \mathrm{~mm})$, containing different rubber sizes at a various percentages. In all Figures namely; (3, 4 and 5$)$, it can be seen that the control specimen $(0 \%$ rubber) achieved generally strains at the peak stresses but the curve shows a much steeper descending branch in comparison to those of the stress-strain curves of mixes with rubber. In Fig. 3 the stress-strain behaviors of $10 \%$ rubber content for rubber size $(3.0-4.0 \mathrm{~mm})$, behave in similar trend to the control specimen $(0 \%$ rubber $)$, but having a small peak. From the figure, it can be observed that there is linear increase of stresses until it reaches its peak before energy is released by specimen's fracture. For this case, the specimens behaved like a brittle material of which the total energy generated upon fracture is elastic energy.

TABLE 1: COMPRESSIVE STRENGTH OF THREE SETS FOR CONTROL AND RUBBERIZED SPECIMENS WITH PARTIAL VOLUME REPLACEMENT 10\%, 20\%, 30\% AND DIFFERENT RUBBER SIZE

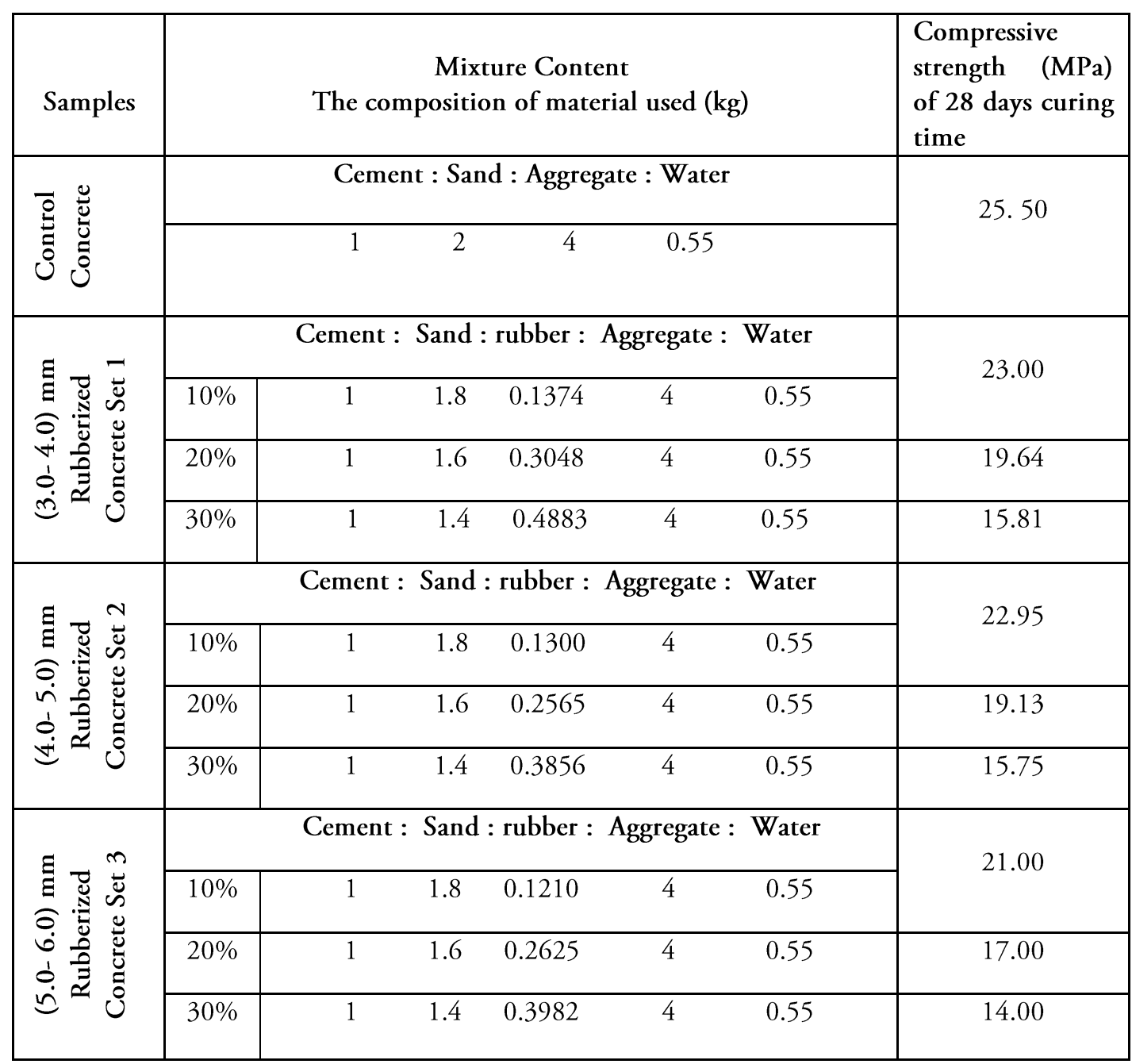




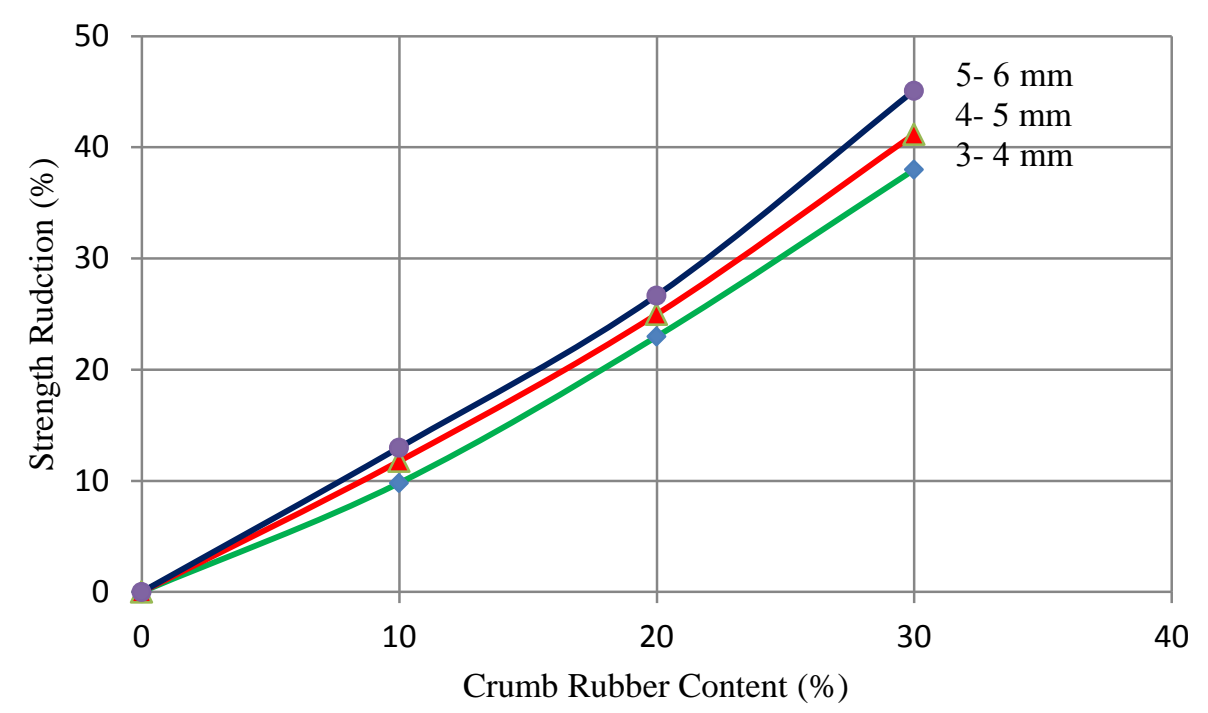

Fig. 2. Strength reductions for the three tested sets

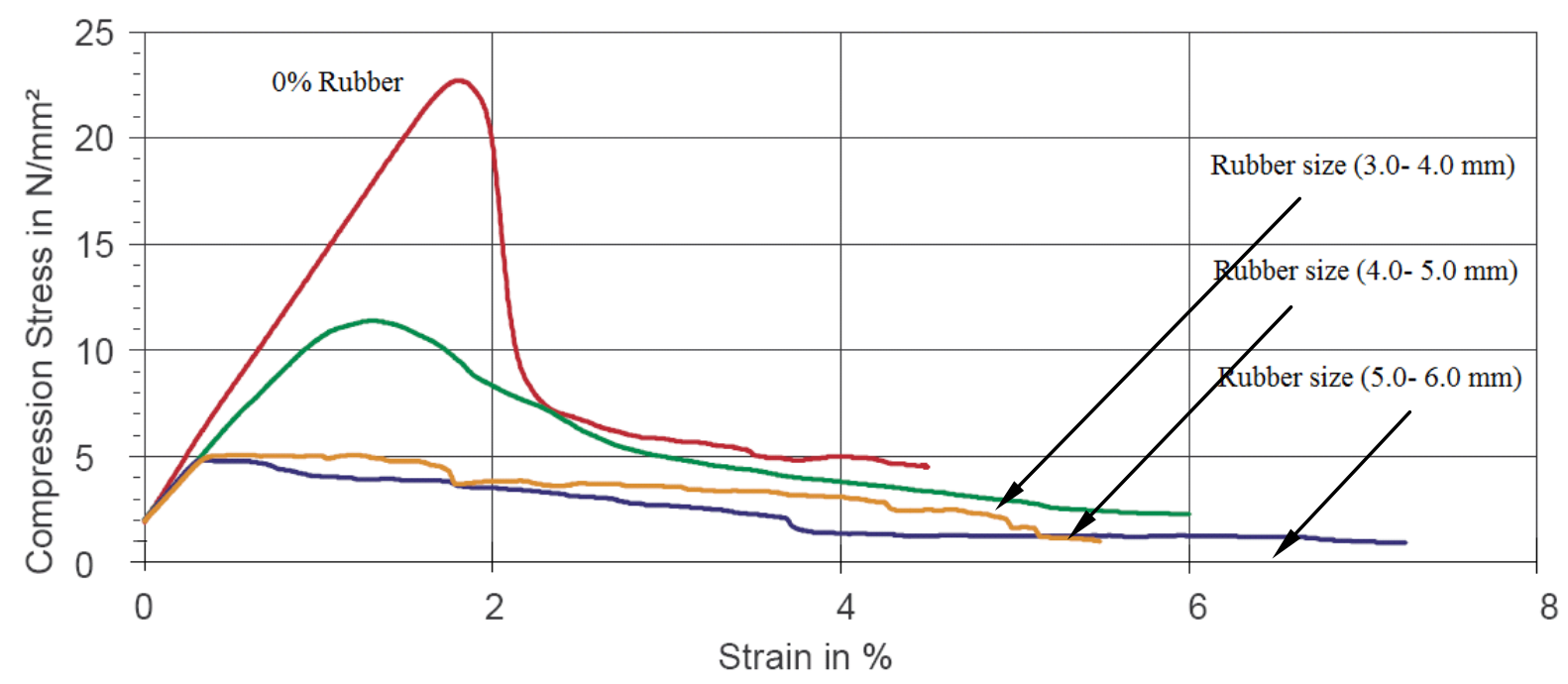

Fig.3. Stress-strain results at $10 \%$ ratios of different rubber sizes

On the other hand, nonlinear behavior is seen for the other two specimens containing sizes $(4.0-5.0 \mathrm{~mm})$, and $(5.0-6.0 \mathrm{~mm})$ rubber. Here, once the peak stress is reached, the specimen continues to yield, as represented by the branch-line. This behavior is similar to the behavior of the tough materials having most of its energy generated upon fracture as plastic energy.

In Fig. 4 the stress-strain behaviors of 20\% rubber content for rubber sizes $(3.0-4.0 \mathrm{~mm})$, and $(4.0-5.0 \mathrm{~mm})$ behave in similar trend to the control specimen ( $0 \%$ rubber), but having a small peak. It also, can be observed that there is linear increase of stresses until it reaches its peak before energy is released by specimen's fracture.

The specimens behaved like a brittle material of which the total energy generated upon fracture is elastic energy. On the other hand, nonlinear behavior is seen for the other specimen containing size $(5.0-6.0 \mathrm{~mm})$ rubber. Here, once the peak stress is reached, the specimen continues to yield, as 
represented by the branch-line. This behavior is similar to the behavior of the tough materials having most of its energy generated upon fracture as plastic energy.

In Fig. 5 the stress-strain behaviors of $30 \%$ rubber content for rubber sizes $(3.0-4.0 \mathrm{~mm})$, $(4.0-5.0 \mathrm{~mm})$ and $(5.0-6.0 \mathrm{~mm})$ do not exhibit a real peak, the curves showing a prolonged plateau though the straining of the material. This show evidence of a ductile fracture behavior as well as an ability to support loads after cracks were generated. This behavior is due the consistent with the ability of the rubber to flex under compression.

\subsection{Evaluation OF WORKability AND UNIT WEIGHT}

The evaluation of workability and unit weight acknowledged through checking the chloride permeability of chosen samples of rubberized concrete and the analysis of the unit weight. Many concrete structures are built today with specifications calling for low-permeability concrete. The construction industry accepts this test procedure as a measurement for determining chloride permeability [23]. This test was created to develop techniques to nondestructively measure the chloride permeability of in-place concrete.
Two chosen samples of $10 \%$ and $20 \%$ crumbed rubber of size $4 \mathrm{~mm}$ have been tested for evaluations of alternative materials, but in practice its use has evolved to applications such as quality control and acceptance testing. Table 2 illustrates the standard of five categories regarding different levels of permeability. Numerical results of this test (total charge passed, in coulombs) can be used as a basis for determining the acceptability of a concrete mixture.

Figure 6 shows the result of the test (total charge passed, in coulombs) can be used as a basis for determining the acceptability of a concrete mixture. The coulombs adjusted value (based on the diameter) was 3046 and 2463 COULOMBS for $10 \%$ and $20 \%$ crumbed rubber respectively. According to Table 2, this concrete mixture is considered as a moderate (2000- 4000). Another test is conducted to evaluate the workability. In this test the unit weight of the samples are considered and the values of partial replacement of the crumb rubber content, the mix proportions and the weight of one specimen $(150 \times 300 \mathrm{~mm})$ are recorded in Table 3. It demonstrates the effect of changing the percentage of crumb rubber over weight of the specimens.

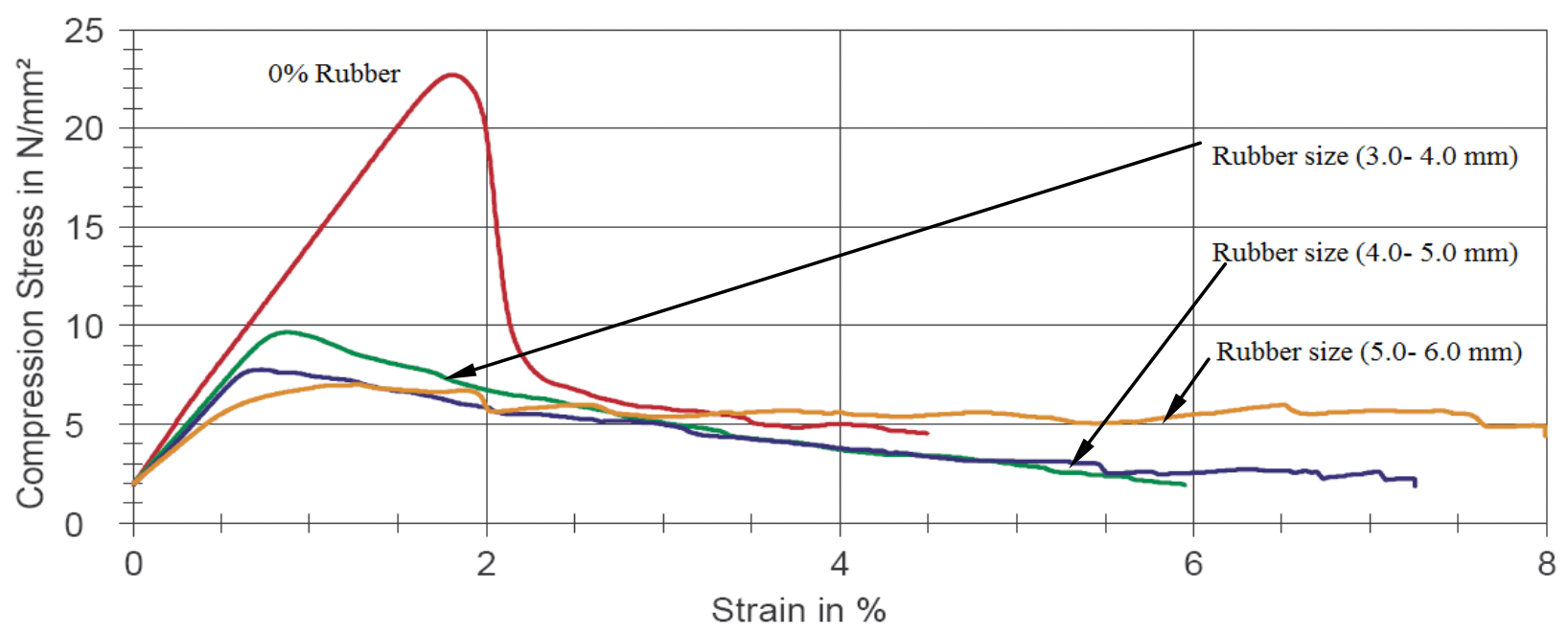

Fig.4. Stress-strain results at $20 \%$ ratios of different rubber sizes 


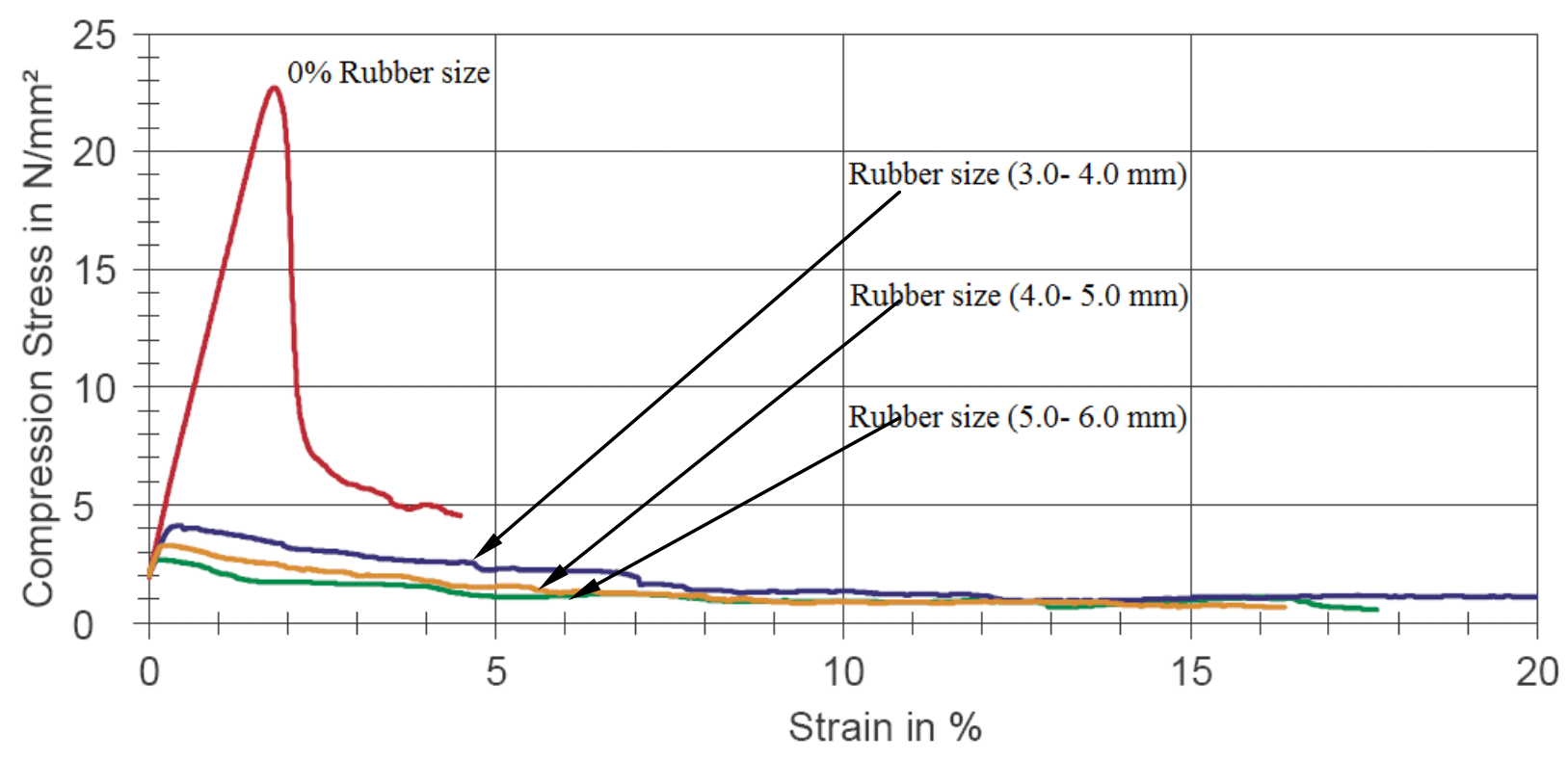

Fig. 5. Stress-strain results at $20 \%$ ratios of different rubber sizes

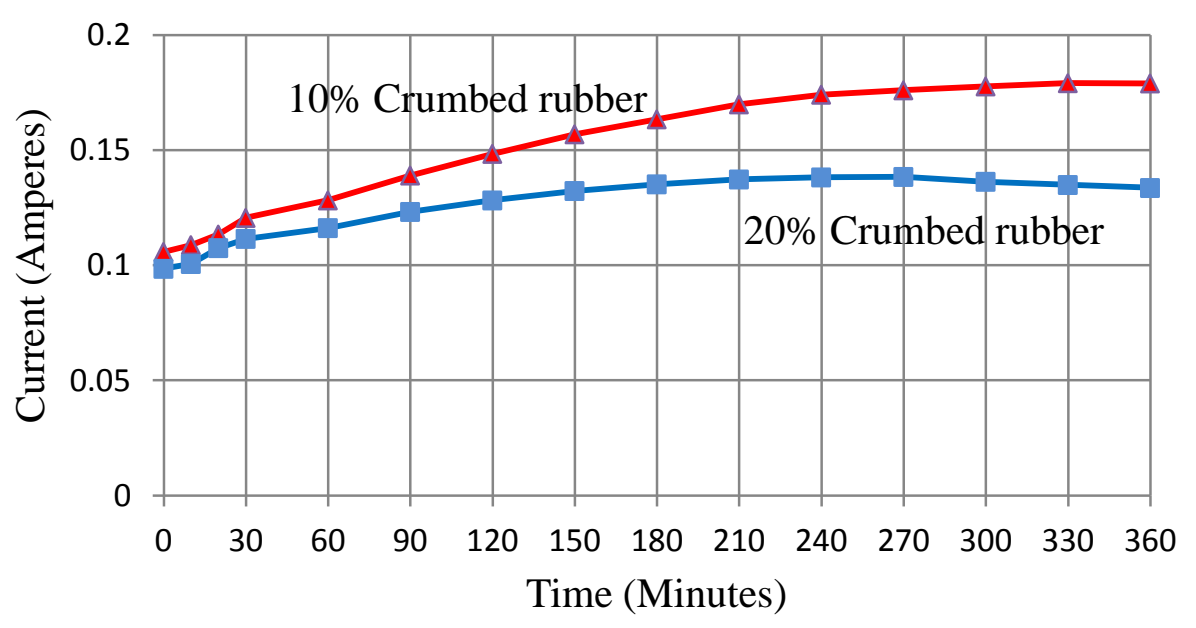

Fig. 6. Rapid chloride permeability tests for $10 \%$ and $20 \%$ crumbed rubber size $4 \mathrm{~mm}$

Table 2: Chloride Permeability Based on Charge Passed ([23])

\begin{tabular}{|c|c|c|}
\hline Charge Passed Chloride & $\begin{array}{l}\text { (Coulombs) } \\
\text { Permeability }\end{array}$ & Typical of \\
\hline$>4,000$ & High & $\begin{array}{c}\text { High W/C ratio }(>0.60) \text { conventional } \\
\text { PCC }\end{array}$ \\
\hline $2,000-4,000$ & Moderate & $\begin{array}{c}\text { Moderate W/C ratio }(0.40-0.50) \\
\text { conventional PCC }\end{array}$ \\
\hline $1,000-2,000$ & Low & Low W/C ratio $(<0.40)$ conventional PCC \\
\hline $100-1,000$ & Very Low & $\begin{array}{l}\text { Latex modified concrete or internally- } \\
\text { sealed concrete }\end{array}$ \\
\hline$<100$ & Negligible & $\begin{array}{l}\text { Polymer-impregnated concrete, Polymer } \\
\text { concrete }\end{array}$ \\
\hline
\end{tabular}


Yanbu Journal of Engineering and Science Vol. 6 (2013)

TABLE 3: MIX PROPORTIONS OF CONTROL AND FRESH RUBBERIZED CONCRETE PROPERTIES (28 DAYS)

\begin{tabular}{|l|l|l|l|}
\hline $\begin{array}{l}\text { Crumb rubber } \\
\text { content (\%) }\end{array}$ & Mix proportions $\left(\mathrm{kg} / \mathrm{m}^{3}\right.$ for one specimen 150×300mm) & Weight of one \\
\cline { 2 - 4 } & Water Cement Coarse Aggregates Fine Aggregates Rubber $(\mathrm{kg})$ \\
\hline
\end{tabular}

\begin{tabular}{|c|c|c|c|c|c|c|}
\hline \multicolumn{7}{l|}{ First Set with crumbed rubber size (3- 4) mm } \\
\hline 0 & 1.25 & 2.25 & 9 & 4.50 & 0 & 13.92 \\
\hline 10 & 1.25 & 2.25 & 9 & 4.05 & 0.1374 & 13.35 \\
\hline 20 & 1.25 & 2.25 & 9 & 3.60 & 0.3048 & 12.97 \\
\hline 30 & 1.25 & 2.25 & 9 & 3.15 & 0.4883 & 12.75 \\
\hline
\end{tabular}

Second Set with crumbed rubber sizes (4- 5) $\mathrm{mm}$

\begin{tabular}{|c|c|c|c|c|c|c|}
\hline 0 & 1.25 & 2.25 & 9 & 4.50 & 0 & 13.92 \\
\hline 10 & 1.25 & 2.25 & 9 & 4.05 & 0.1300 & 13.28 \\
\hline 20 & 1.25 & 2.25 & 9 & 3.60 & 0.2565 & 12.90 \\
\hline 30 & 1.25 & 2.25 & 9 & 3.15 & 0.3856 & 12.65 \\
\hline
\end{tabular}

Third Set with crumbed rubber sizes (5- 6) $\mathrm{mm}$

\begin{tabular}{|c|c|c|c|c|c|c|}
\hline 0 & 1.25 & 2.25 & 9 & 4.50 & 0 & 13.92 \\
\hline 10 & 1.25 & 2.25 & 9 & 4.05 & 0.1210 & 13.20 \\
\hline 20 & 1.25 & 2.25 & 9 & 3.60 & 0.2625 & 12.80 \\
\hline 30 & 1.25 & 2.25 & 9 & 3.15 & 0.3982 & 12.50 \\
\hline
\end{tabular}

It also demonstrates that increasing the percentage of the rubber in the specimens would reduce the weight of the specimens, and the mix still produced a workable mix with comparison to the control mix.

Table 4 illustrates the required compressive strength for the different application categories of the structural light weight concrete (LWC) as specified by Neville [24] which has been adopted for building codes. Due to the low specific gravity of the rubber, the concrete with crumb rubber can be classified as light weight concrete. This can also be supported by the work conducted by Pierce and Blackwell [25].

The minimum strength required for structural light weight concrete is $17 \mathrm{MPa}$, as shown in Table 4. Using $20 \%$ crumb rubber of all the three sizes can achieve an average strength of 18.59 MPa. Therefore, the rubberized concrete containing up to $20 \%$ crumb rubber can be used in light weight structural concrete. The second category given in Table 4, requiring compressive strength of 7-17 $\mathrm{MPa}$ for moderate concrete can be also achieved with increasing the partial replacement of the rubber up to $30 \%$ and increasing the sizes up to $6.0 \mathrm{~mm}$.

Figure 7 shows that the weights of all the three rubberized concrete specimens are reduced as the crumbed rubber ratios and sizes are increased. In other words, at $10 \%$ the decrease in weight was $(0.57,0.60$, and 0.72$)$ $\mathrm{kg}$ for the sizes $(3.0-4.0 \mathrm{~mm}),(4.0-5.0 \mathrm{~mm})$, and $(5.0-6.0 \mathrm{~mm})$ respectively.

TABle 4: PRACTICAL RANGE OF CATEGORIES OF LIGHT WEIGHT CONCRETE (NEVILLE [24])

\begin{tabular}{|l|l|l|}
\hline \multicolumn{1}{|c|}{ Categories } & $\begin{array}{l}\text { Density } \\
\text { range } \\
\left(\mathbf{k g} / \mathbf{m}^{3}\right)\end{array}$ & $\begin{array}{l}\text { Minimum } \\
\text { strength (MPa) }\end{array}$ \\
\hline $\begin{array}{l}\text { Structural light } \\
\text { weight concrete }\end{array}$ & $1350-1900$ & 17 \\
\hline $\begin{array}{l}\text { Moderate } \\
\text { strength concrete }\end{array}$ & $1900-800$ & \multicolumn{1}{|c|}{$7-17$} \\
\hline $\begin{array}{l}\text { Low density } \\
\text { concrete }\end{array}$ & $300-800$ & $\begin{array}{l}\text { Used for non- } \\
\text { structural purposes } \\
\text { (insulation panel, } \\
\text { pavements, blocks, } \\
\text { etc.) }\end{array}$ \\
\hline
\end{tabular}




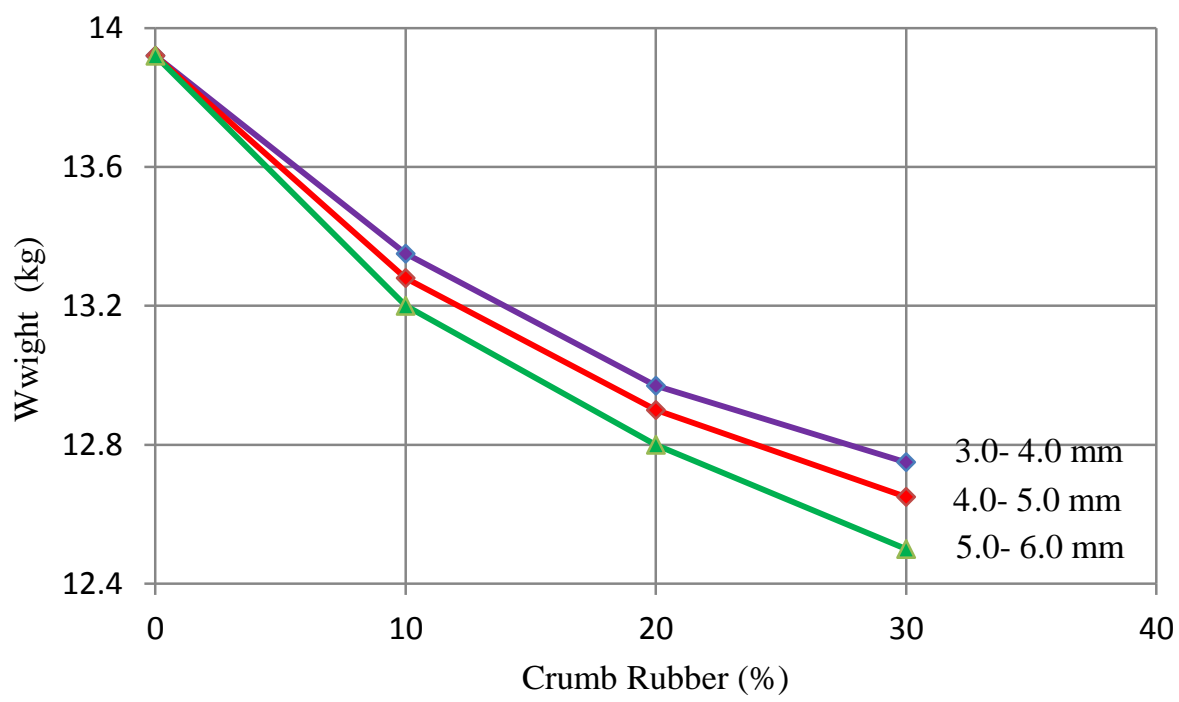

Figure 7 Effect of different partial replacement of crumbed rubber at different sizes on the weight of three sets specimens

At $20 \%$ the decrease was $(0.95,1.18$, and 1.42) $\mathrm{kg}$ for the same sizes. And for $30 \%$ the decrease was $(1.2,1.3$, and 1.4$) \mathrm{kg}$ also for the same sizes. Therefore, for sizes from (3.0- 4.0) $\mathrm{mm}$, and up to $20 \%$ partial replacement it can be considered as structural light weight concrete. On the other hand, for sizes from (5.0 to 6.0$) \mathrm{mm}$, and up to $30 \%$ partial replacement it can be considered as moderate strength concrete.

\section{CONCLUSION}

Based on the experimental results, the following conclusions can be drawn:

1. Rubberized concrete mix using recycled tires agreed with the values of compressive test for light and moderate weight structural concrete as shown in Table 4. Although the strength of rubberized concrete is reduced with an increase in the rubber content, its lower unit weight meets the criteria of light weight concrete that fulfill the strength requirements in Table 4. Although it is not recommended to use this rubberized concrete in structural elements where high strength is required, it can be used in many other construction elements like partition walls, road barriers, pavement, sidewalks, etc. which are in high demand in the construction industry.

2. As a result of adding rubber, the tested specimens behaved like a brittle material of which the total energy generated upon fracture is elastic energy at $10 \%$ and $20 \%$ ratios for size $4 \mathrm{~mm}$. The nonlinear behavior represented by the branch-line is seen for the other two sizes $(5.0 \mathrm{~mm}$, and $6.0 \mathrm{~mm})$ rubber and the specimen continues to yield. The stress-strain behaviors of $30 \%$ rubber content for all rubber sizes, do not exhibit a real peak, the curves showing a prolonged plateau though the straining of the material. This show evidence of a ductile fracture behavior as well as an ability to support loads after cracks were generated. This behavior is due the consistent with the ability of the rubber to flex under compression.

3. The results graded the thoughtful addition of tire waste to reinforced concrete can offer a valuable disposal 
application for the tire waste while enhancing the performance of concrete for certain types of service.

4. Due to the elasticity of rubber particles, rubberized concrete can prevent micro cracks from rising and can absorb the strain energy, thus improving the impact resistance of concrete.

\section{ACKNOWLEDGEMENTS}

The author would like to acknowledge the support of the Saudi Rubber Products Co. (SARPC) Al-Khobar, for supplying the recycled tire rubber. On other hand the author would like to thank Osaimi Engineering Office, Yanbu Al Sinaiyah, for their technical assistance in the laboratory.

\section{REFERENCES}

[1] Hakkinen, T. and Kronlof, A. Environmental Effect of Building Materials, VTT Tiedotteita 1591, Espoo, Technical Research Center of Finland, pp. 25-61, 1994.

[2] Mehat, P. K., Bringing the Concrete Industry Into a New Era of Sustainable Development, Mario Collepardi Symposium on Advances in Concrete Science and Technology, pp. 49-67, 1997.

[3] Papakonstantinou, C. G., Tobolski, M. J. Use of Waste Tire Steel Beads in Portland Cement, Concrete Cement and Concrete Research, 36 (9), pp. 1686-1691, 2006.

[4] Silvestravičiūtè, I., Šleinotaitė-Budrienè, L., Possibility to Use Scrap Tires as an Alternative Fuel in Cement Industry Environmental Research, Engineering and Management, 3 (21), pp. 38 48, 2000 .

[5] Segre, N., Joekes, I. Use of Tire Rubber Particles as Addition to Cement Paste, Cement and Concrete Research 30 (9), pp. 1421 - 1425, 2000.

[6] Shuaib, Ahmad, Fedroff, David, Sayas, Banu Zeynep, and Freeze-Thaw Durability of Concrete With Ground Waste Tire Rubber, Transportation Research Record 1574, 1997.

[7] Fuminori Tomosawa, Takafumi Noguchi and Masaki Tamura, The way concrete recycling should be. Journal of Concrete Technology, 3, pp. 3-16, 2005.

[8] Topcu, I.B., The Properties of Rubberized Concrete, Cement. Concrete Research, 25 (2), pp. 304-310, 1995.

[9] Segre, N., Joekes, I. Use of Tire Rubber Particles as Addition to Cement Paste, Cement and Concrete Research 30 (9), pp. 1421 - 1425, 2000.

[10] Khatib, Z.K. and F.M. Bayomy, Rubberized Portland cement concrete, Journal of Material in Civil Engineering ASCE, 11 (3), pp.206-213, 1999.

[11] Kamil Kaloush, Doug Carlson, George Way and Mark Belshe, 2004. Crumb Rubber ConcretePrecast of the future? 2004. http://www.precast.org/publications/solutions/cr umb_rubber.htm

[12] Fatuhi, N. and Clark, N., Cement Based Materials Containing Tire Rubber, Construction Building Materials, 10 (4), pp. 229-236, 1996.

[13] Lee, B. I., Burnett, L., Miller, T., Postage, B., Cuneo, J., Tire Rubber Cement Matrix Composites, Journal of Material Science Letter 12 (13), pp. $967-968,1993$.

[14] Eldin, N. N., Senouci, A. B., Measurement and Prediction of the Strength of Rubberized Concrete, Cement \& Concrete Composites 18, pp. 135 - 139, 1996.

[15] Goulias, D. G. and Ali, A. H., Non-Destructive Evaluation of Rubber Modified Concrete, in Proceedings, Special Conference ASCE, New York, pp. 111-120, 1997.

[16] Topcu, I. B. and Avcular, N., Analysis of Rubberized Concrete as a Composite Material, Cement and Concrete Research, Vol. 27, No. 8, pp. 1135-1139, 1997.

[17] Fedroff, D., Ahmad, S. and Savas, B. Z., Mechanical Properties of Concrete with Ground Waste Tire Rubber, Transportation Research Record, No. 1532, pp. 66-72, 1996.

[18] Neville, A.M., Properties of Concrete. Addison Wesley Longman limited, England, 1995

[19] Hernandez-Olivares, F., Barluenga, G., Bollati, M., Witoszek, B. Static and Dynamic Behavior of Recycled Tire Rubber-filled Concrete, Cement and Concrete Research 32 (10), pp. 1587-1596, 2002. 
[20] Topcu, I.B., The Properties of Rubberized Concrete, Cement. Concrete Research, 25 (2), pp. 304-310, 1995.

[21] Saudi Building Code Committee, First Edition: January 2007. ISBN: 9960-9883-5-X, www.sbcnc.gov.sa Bignozzi, M. C., Sandrolini, F.

[22] Tyre Rubber Waste Recycling in Self-compacting Concrete Cement and Concrete Research 36 (4), pp. $735-739,2006$.

[23] ASTM C1202 - 10 Standard Test Method for Electrical Indication of Concrete's Ability to Resist Chloride Ion Penetration, http://www.astm.org/Standards/C1202.htm

[24] Neville, A.M., Properties of Concrete. Addison Wesley Longman limited, England, 1995

[25] Pierce, C.E., and Blackwell, M.C., Potential of scrap tire rubber as lightweight aggregate in flowable fill, Waste Management, 23, pp.197208, 2003. 


\title{
بعض الخصائص الميكانيكية للخرسانة المطاطية
}

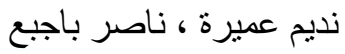 \\ كلية ينبع الصناعية، المملكة العربية السعودية
}

(الملخص:

تمثل نفايات الإطار ات مشكلة كبيرة بالنسبة للبيئة، و التوصل لطرق بيئية صحيحة للتخلص منها هو من التحديات الجذابة. إن إعادة معالجة هذه النفايات هي إحدى الوسائل المستخدمة للتخلص من نفايات الإطارات وذلك لحماية البيئة و المجتمع ـ هذا البحث يبين النتائج المترتبة على دمج الجزيئات المطاطة للإطارات المستعطلة على بعض الخواص الميكانيكية للخرسانة. ويتم تحقيق الهدف من هذا العمل لتسليط الضوء على استخدام الإطارات المطاطية كبديل جزئي من الركام الناعم لإنتاج الخرسانة بالمطاط. من أجل التطبيق في مختلف التطبيقات الهندسية الو اعدة، وتثارك ثلاثة أحجام مختلفة كبديل جزئي من فتات المطاط في (10\%، 20\%، 30\%) من حجم الركام الناعم في الخلطات الخراسانية. وقد أعدت ثلاث مجموعات مختلفة ويم اختبار ها من حيث مقاومة الضغط وضغط الإجهاد والانفعال وقابلية التشغيل، وتقييم فاعليتها من خلال اختبارات الوزن واختبار النفاذة. و أظهرت النتائج أن استخدام المطاط بمقاسات ونسب مختلفة عمل على خفض جميع أنواع مقاومة الضغط. وقد أنشارت النتائج إلى أن أحجام مختلفة من المطاط تخفض وزن الخرسانة وقابليتها التشغيلية، والتي تراوحت بين

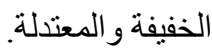

